\title{
Mortalitas Larva Litopenaeus vannamei Pada Penerapan Perbedaan Sistem Filtrasi Air Media Pemeliharaan
}

\author{
Sunaryo ${ }^{1,2 *}$, I Nyoman Widiasa ${ }^{3}$, Ali Djunaedi', Priyo Sasmoko4 \\ 'Departemen IImu Kelautan, Fakultas Perikanan dan IImuKelautan, Universitas Diponegoro \\ 2 Pusat Program Pelayanan Pengabdian Umum, Universitas Diponegoro \\ 3Departemen Teknik Kimia, Fakultas Teknik, Universitas Diponegoro \\ ${ }^{4}$ Departemen Teknik Elektro, Sekolah Vokasi, Universitas Diponegoro \\ JI. Prof. Soedarto, SH. Tembalang, Semarang 50275 Indonesia \\ Email: snyifm@yahoo.com
}

\begin{abstract}
Mortality of Litopenaeus vannamei larvae with the different filtration system of seawater as media for rearing
\end{abstract}

Mortality of Litopenaeus vannamei larvae in shrimp hatcheries centers is commonly high. Therefore, innovation to solve the problem through water quality management improvement in necessary by applying ultrafiltration system to shrimp hatchery. This experiment aims to determine larval mortality rate in response to the application of different filtration systems. Experiments were conducted using 4 milions larvae of L. vannamei shrimp. Shrimp larvae were kept in 4 tanks, each volume was $8 \mathrm{~m}^{3}$. Two reservoirs tank were equipped with ultrafiltration and other systems used sand-filter as controls. Implementation of experimental activities used action research method with two repetitions. Observation were conducted on mortality of shrimp larvae and water quality, i.e., temperature, salinity, $\mathrm{pH}$, TSS, dissolved $\mathrm{O}_{2}, \mathrm{NH}_{3}$ and $\mathrm{NO}_{3}{ }^{-2}$. The result showed the shrimp larvae reared with the application of ultrafiltration system had significantly lower percentage of mortality $(55,02 \%)$ compared with filtering using sand-filter $(59,58 \%)$. Concentrations of Ammonia (NH3-N) and TSS content increased along with longer period of larval rearing.

Keywords: Mortality; Seeding; Litopenaeus vannamei; Ultrafiltration; Sandfilter

\begin{abstract}
Abstrak
Mortalitas larva udang Litopenaeus vannamei di sentra pembenihan masih tinggi. Inovasi sistem pengendalian kualitas air pada media pembenihan udang perlu dilakukan. Percobaan dilakukan untuk mengetahui respon tingkat mortalitas larva Litopenaeus vannamei denan penerapan perbedaan sistim filtrasi. Pelaksanaan percobaan menggunakan metode action research dengan pengulangan 2 kali. Percobaan dilakukan dengan menggunakan larva Udang Litopenaeus vannamei stadia larva sebanyak 4 juta ekor. Larva Udang dipelihara dalam 4 buah bak. Dua buah bak dilengkapi dengan sistem ultrafiltrasi dan bak lainnya menggunakan sandfilter sebagai kontrol. Pengamatan dilakukan terhadap mortalitas larva udang, suhu, salinitas, pH, MPT, $\mathrm{O} 2$ terlarut, $\mathrm{NH}_{3}$ dan $\mathrm{NO}_{3}{ }^{-2}$. Hasil penelitian menunjukkan bahwa rata-rata mortalitas Larva udang Vannamei yang dipelihara dengan pola pemeliharaan dengan penerapan sistim ultrafiltrasi adalah $55.02 \%$ yang berbeda sangat nyata $(p>0,01)$ dibandingkan dengan penerapan pola pemeliharaan menggunakan sandfilter yaitu 59,58\%. Kualitas air media pemeliharaan larva udang Vannamei, terutama: kandungan Ammoniak $\left(\mathrm{NH}_{3}-\mathrm{N}\right)$ dan MPT menunjukkan semakin meningkat dengan semakin lamanya waktu pemeliharaan.
\end{abstract}

Kata Kunci: Mortalitas; Kualitas Air; Pembenihan; vaname; Ultrafiltrasi; Sandfilter 


\section{PENDAHULUAN}

Udang Vannamei (Litopenaeus vannamei) merupakan salah satu sumberdaya hayati laut yang sebarannya sangat luas dan banyak dibudidayakan di Indonesia.. Produksi udang Indonesia dalam kurun waktu lima tahun terakhir mengalami peningkatan sebesar 13,9\% per tahun (Anonimus, 2016). Sementara itu mortalitas benih udang yang tinggi merupakan permasalahan yang sering dihadapi oleh para petambak dan pembenih (Hatchery) Udang Vannamei (Anita et al., 2017).

Peningkatan produksi harus diimbangi dengan pasokan benih yang berkualitas dan dan berkelanjutan. Akan tetapi sampai saat ini kebutuhan benih udang belum dapat tercukupi. Hal tersebut diakibatkan masih tingginnya mortalitas benih udang di sentra pembenihan. Mortalitas yang tinggi disebabkan oleh berbagai faktor, salah satunya adalah menurunnya kualitas air media pemeliharaan benih udang (Amrillah et al., 2015)

Inovasi sistem pengendalian kualitas air pada media pembenihan udang perlu dilakukan. Pengendalian kualitas air media pemeliharaan larva udang dapat dilakukan dengan berbagai cara. Cara yang banyak dilakukan adalah dengan mengganti air media yang baru, melakukan sirkulasi media dan menambahkan bahan tertentu pada media seperti probiotik dan antibotik. Penerapan sistem filtrasi air, perlakuan ozonisasi, penyinaran ultraviolet dapat menjadi komponen penunjang yang dapat menghindari wabah penyakit pada kegiatan pembenihan. Melalui pengelolaan kualitas air secara benar, maka kebutuhan akan obatobatan dan antibiotika dapat dikurangi (Kordi dan Andi, 2007). Berbagai upaya tersebut belum dapat menekan mortalitas yang signifikan.

Penurunan kualitas air merupakan salah satu permasalahan pemicu terjadinya kematian benih udang yang hingga sekarang kelompok pembenih udang belum menemukan solusi yang optimal. Keterbatasan kemampuan kelompok pembenih udang dalam memecahkan permasalahan ini menyebabkan rendahnya produksi Udang Vannamei dari hasil kegiatan pembenihan. Pada penelitian telah dilakukan pengelolaan air dengan berbagai macam sistim filtrasi untuk memenuhi berbagai kebutuhan industri dan konsumsi air minum (Wenten et al., 1998; Wenten dan Widiasa, 2004; Widiasa dan Wenten, 2004; Widiasa, 2005; Widiasa dan Wenten, 2005).

Oleh sebab itu diperlukan upaya yng lebih inovatif supaya dapat menekan mortalitas benih udang. Salah satu yang akan dicoba pada penelitian ini adalah dengan penerapan sistem ultrafiltrasi pada proses produksi benih Udang Vannamei. Dalam sistim filtrasi ini akan dilakukan penyaring air secara bertingkat sehingga diharapkan akan didapatkan kualitas air yang lebih bersih dari berbagai pathogen.

Penelitian ini bertujuan untuk tingkat mortalitas larva Udang Vannamei melalui perbedaan penerapan sistem filtrasi pada proses produksi benih Udang Vannamei. Pelaksanaan penelitian dilakukan di hatchery Laboratorium Pengembangan Wilayah Pantai "Prof. Dr. Gatot Rahardjo Joenoes, Jepara", Fakultas Perikanan dan IImu Kelautan Undip.

\section{MATERI DAN METODE}

Kegiatan produksi benih menggunakan materi uji berupa penerapan sistem ultrafiltrasi pada Hatchery Udang Vannamei yang dibandingkan dengan penggunaan sistem pemeliharaan pola lama yang dilakukan oleh para pembenih udang setempat (Gambar 1). Larva Udang Vannamei (L. vannamei) stadia Nauplius dipergunakan sebagai hewan percobaan dengan jumlah keseluruhan 4.000.000 ekor. Larva diperoleh dari tempat pembenihan udang BBPBAP Jepara.

Larva dipelihara dengan sistem sirkulasi tertutup dalam bak pemeliharaan larva, volume $8 \mathrm{~m} 3$ dengan kepadatan 100 ekor/L dan 1 buah tandon air yang dilengkapi sistem filtrasi sand filter dan ultrafiltrasi. Pemeliharaan menggunakan air laut, yang sebelumnya difilter dengan menggunakan sand filter dan ultrafiltrasi serta disanitasikan dengan larutan chlorin $125 \mathrm{mg} / \mathrm{L}$ (Leblanc dan Overstreet, 1991). Larva dipelihara pada salinitas 34 ppt, 
suhu $28-32{ }^{\circ} \mathrm{C}, \mathrm{pH}$ 6,5 - 8, oksigen $4-7,5 \mathrm{mg} / \mathrm{L}$, kedalaman air $70-120 \mathrm{~cm}$.

Pakan uji yang dipergunakan di dalam penelitian berupa pakan hidup (Skeletonema sp., Spirulina powder, pakan buatan untuk Zoea, Mysis dan Artemia sp. dengan frekuensi pemberian 6 kali sehari (Mc.Vey, dan Fox, 1983)

Bahan dan peralatan yang dipergunakan dalam penelitian, seperti berikut: bahan dan peralatan untuk analisis kualitas air, seperti: thermometer, refraktometer (ATAGO Master-S Mill), $\mathrm{pH}$ meter (Extech/ pH 300), oksimeter (YSI 550A-12ft), UVVIS Spectrophotometer (Agilent Cary 60 UVVis), sechii disc, Timbangan Digital (DURASCALE DAB200), jangka sorong (Jonnesaway MTC 1150), mikroskop (Motic BA210), mikrometer okuler, haemocytometer (Assistant).

Pelaksanaan kegiatan percobaan menggunakan metode action research, yaitu: suatu metode percobaan yang dilaksanakan secara langsung di lapangan yang disaksikan oleh publik/ kelompok sasaran pengguna kegiatan (Nasir, 1988). Perlakuan yang diterapkan pada percobaan ini, yaitu: A (Sistem pemeliharaan pola lama (dengan penerapan sand filter dalam penyediaan air) yang dilakukan para kelompok pembenih udang sebagai kontrol); B (aplikasi teknologi Ultrafiltrasi pada Hatchery Udang Vannamei). Parameter pengamatan dilakukan terhadap mortalitas benih udang. Selain itu diamati pula faktor - faktor pendukung berupa kualitas air media pemeliharaan, berupa: suhu, salinitas, $\mathrm{pH}$, MPT, oksigen terlarut, ammoniak, ammonium dan nitrit.

Data yang didapatkan dari hasil analisis dan perhitungan parameter pengamatan pada tiap - tiap perlakuan dianalisis dengan menggunakan analisis varians (Steel and Torrie, 1980; Sudjana, 1982).

\section{HASIL DAN PEMBAHASAN}

Mortalitas larva udang Vannamei yang dihasilkan selama penelitian berlangsung dapat dilihat pada Tabel 1. Larva udang Vannamei pada stadia Nauplius (N6) yang dipelihara pada air media pemeliharaan larva yang sebelumnya difilter dengan sand filter nilai rerata mortalitas sebesar $7,20 \%$. Sebaliknya larva udang Vannamei yang telah dipelihara pada air media pemeliharaan larva udang yang terlebih dahulu dilakukan proses filtrasi dengan menggunakan filter ultrafiltrasi pada penyiapannya, rerata mortalitasnya sebesar $2,68 \%$.

Hasil analisis ragam dari kedua variabel yang diteliti menunjukkan bahwa respon yang ditimbulkan akibat dari perbedaan perlakuan penggunaan sistim penyiapan air media pemeliharaan pada awal kegiatan pelaksanaan pemeliharaan larva udang Vannamei yang berbeda, yaitu penerapan sistim sand filter dan sistem ultra filtrasi menghasilkan mortalitas larva udang Vannamei yang berbeda sangat nyata $(p<0,01)$.
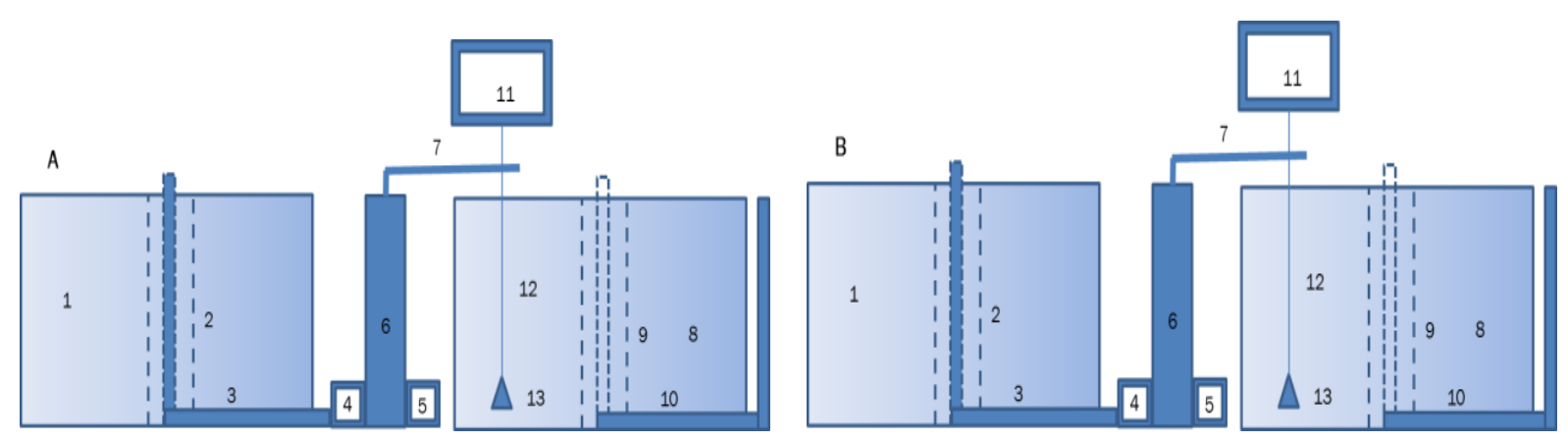

Gambar 1. Sistem Filtrasi Pada Backyard Hatchery Udang Vannamei.

Keterangan: A. Bak Dengan Sandfilter (Pola Lama); 1. Bak Reservoar; 2. Saringan mesh size $25 \mu \mathrm{m}$, 3. Pipa Buangan, 4 Pompa Air, 5. Pompa backwash, 6. Sandfilter, 7. Pipa Inlet, 8. Bak Pemeliharaan Larva $(2 \times 3 \times 1,5$ $\mathrm{m}^{3}$ ), 9. Saringan mesh size $25 \mu \mathrm{m}$, 10. Pipa Buangan, 11. Blower, 12. Slang aerasi, 13. Batu aerasi. B. Bak Dengan Filter Ultrafiltrasi, 6. Ultrafilter, C. Gambar Ultrafilter, D. Bak Pemeliharaan Larva $\left(2 \times 3 \times 1,5 \mathrm{~m}^{3}\right)$. 
Larva udang Vannamei pada stadia Zoea (Z3) yang dipelihara pada air media pemeliharaan larva yang sebelumnya difilter dengan sand filter, rerata mortalitasnya sebesar 14,52 \%. Sebaliknya larva yang telah dipelihara pada air media pemeliharaan larva udang yang terlebih dahulu dilakukan proses filtrasi dengan menggunakan filter ultrafiltrasi pada penyiapannya, mortalitasnya sebesar $6,68 \%$.

Hasil analisis ragam dari kedua variabel yang diteliti menunjukkan bahwa respon yang ditimbulkan akibat dari perbedaan perlakuan penggunaan sistim penyiapan air media pemeliharaan pada awal kegiatan pelaksanaan pemeliharaan larva yang berbeda, yaitu penerapan sistim sand filter dan sistem ultra filtrasi menghasilkan mortalitas yang berbeda sangat nyata $(p<0,01)$.

Pada Tabel 1 dapat dijelaskan bahwa larva udang Vannamei pada stadia Mysis (M3) yang dipelihara pada air media pemeliharaan larva yang sebelumnya mengalami sistim filtrasi dengan sandfilter, rerata mortalitasnya sebesar 27 \%.. Sebaliknya larva yang telah dipelihara pada air media pemeliharaan larva yang terlebih dahulu dilakukan proses filtrasi dengan menggunakan filter ultrafiltrasi pada penyiapannya, rerata mortalitasnya sebesar $10,91 \%$.

Hasil analisis ragam dari kedua variabel yang diteliti menunjukkan bahwa respon yang ditimbulkan akibat dari perbedaan perlakuan penggunaan sistim penyiapan air media pemeliharaan pada awal kegiatan pelaksanaan pemeliharaan larva yang berbeda, yaitu penerapan sistim sand filter dan sistem ultrafiltrasi menghasilkan mortalitas yang berbeda sangat nyata $(p<0,01)$.

Larva udang Vannamei pada stadia Postlarva (PL5) yang dipelihara pada air media pemeliharaan larva yang sebelumnya difilter dengan sand filter, rerata mortalitasnya sebesar 37,65 \% (Tabel 1). Sebaliknya larva yang telah dipelihara pada air media pemeliharaan larva yang terlebih dahulu dilakukan proses filtrasi dengan menggunakan filter ultrafiltrasi, rerata mortalitasnya sebesar $33,82 \%$.

Hasil analisis ragam dari kedua variabel yang diteliti menunjukkan bahwa respon yang ditimbulkan akibat dari perbedaan perlakuan penggunaan sistim penyiapan air media pemeliharaan pada awal kegiatan pelaksanaan pemeliharaan larva yang berbeda, yaitu penerapan sistim sand filter dan sistem ultrafiltrasi menghasilkan mortalitas postlarva (PL5) berbeda sangat nyata $(p<0,01)$.

Postlarva udang Vannamei yan dipelihara sampai dengan PL10, yang dipelihara pada air media pemeliharaan larva yang sebelumnya mengalami filtrasi dengan sand filter, rerata mortalitasnya sebesar $59,58 \%$. Sebaliknya larva yang telah dipelihara pada air media pemeliharaan larva yang terlebih dahulu dilakukan proses filtrasi dengan menggunakan filter ultrafiltrasi rerata mortalitasnya sebesar 55,02.

Hasil analisis ragam dari kedua variabel yang diteliti menunjukkan bahwa respon yang ditimbulkan akibat dari perbedaan perlakuan

Tabel 1. Mortalitas Larva Udang Vannamei Pada Perbedaan Penerapan Sistim Filtrasi Air Media Pemeliharaan

\begin{tabular}{ccccccccccc}
\hline Perlakuan & N6 (ekor) & N6 (\%) & Z3 (ekor) & Z3 (\%) & M3 (ekor) & M3 (\%) & PL5 (ekor) & PL5 (\%) & PL10 (ekor) & PL10 (\%) \\
\hline SF1 & 928.400 & 7,16 & 852.900 & 14,71 & 730.870 & 26,91 & 620.254 & 37,97 & 392.600 & 60,74 \\
SF2 & 927.600 & 7,24 & 856.600 & 14,34 & 729.105 & 27,09 & 626.698 & 37,33 & 415.800 & 58,42 \\
Rerata SF & 928.000 & 7,20 & 854.750 & 14,52 & 729.987 & 27,00 & 623.476 & 37,65 & 404.200 & 59,58 \\
ISD & 566 & 0,06 & 2.616 & 0,26 & 1.248 & 0,12 & 4.557 & 0,46 & $16.404,88$ & 1,64 \\
UTF1 & 972.606 & 2,74 & 932.335 & 6,77 & 891.122 & 10,89 & 660.291 & 33,97 & 445.785 & 55,42 \\
UTF2 & 973.700 & 2,63 & 933.973 & 6,60 & 890.605 & 10,94 & 663.222 & 33,68 & 453.700 & 54,63 \\
Rerata UTF & 973.153 & 2,68 & 933.154 & 6,68 & 890.864 & 10,91 & 661.756 & 33,82 & 449.743 & 55,02 \\
ISD & 774 & 0,08 & 1.158 & 0,12 & 366 & 0,04 & 2.072 & 0,21 & $5.596,75$ & 0,56 \\
\hline
\end{tabular}


penggunaan sistim penyiapan air media pemeliharaan pada awal kegiatan pelaksanaan pemeliharaan larva yang berbeda, yaitu penerapan sistim sand filter dan sistem ultrafiltrasi menghasilkan mortalitas yang berbeda sangat nyata $(p<0,01)$.

Pada Gambar 2 menunjukkan bahwa kelulushidupan larva udang Vannamei yang dipelihara pada sistim yang berbeda dalam persiapan awal air media pemeliharaan larva, keduanya mengalami penurunan mulai dari awal pemeliharaan sampai akhir pemeliharaan. Pemeliharaan larva udang Vannamei dengan menggunakan sand filter dihasilkan penurunan kelulushidupan nauplius rerata sebesar 7,2\%, Zoea rerata sebesar 14,52 $\%$, Mysis rerata sebesar 27,0 \%, Postlarva rerata sebesar 37,65\%, Postlarva 10 rerata sebesar $59,58 \%$ dan pada penggunaan sistim pemeliharaan larva udang dengan menggunakan sistim ultrafiltrasi dihasilkan kenaikan mortalitas nauplius rerata sebesar $2,68 \%$, Zoea rerata sebesar 6,68 \%, Mysis rerata sebesar 10,91\%, Postlarva5 rerata sebesar $33,82 \%$, Postlarva 10 rerata sebesar $55,03 \%$ (Gambar 2).

Mortalitas larva udang secara umum disebabkan oleh berbagai macam faktor, di antaranya adalah faktor internal dan eksternal. Faktor internal yang sangat berpengaruh antara lain faktor genetik dari masing - masing larva udang itu sendiri. Faktor kualitas larva udang yang dipelihara, seperti kemampuannya dalam bertahan terhadap penyakit sangat berperan penting dalam mempertahankan kelulushidupan larva. Demikian juga faktor eksternal terutama dalam kemampuannya untuk beradaptasi terhadap perubahan faktor lingkungan, seperti: suhu, salinitas, pH, ammoniak, oksigen terlarut dalam air dan sebagainya merupakan faktor penting yang sangat berpengaruh terhadap mortalitas larva udang (Mc.Vey, dan Fox, 1983; Widodo et al., 2011; Amrillah et al., 2015; Syukri dan llham, 2016; Anita et al., 2017). Kemampuan adaptasi larva udang pada stadia nauplius terhadap perubahan lingkungan selama transportasi juga mempunyai peran yang cukup besar terhadap mortalitas larva.

Adaptasi larva udang terhadap perubahan faktor lingkungan saat penebaran di lingkungan air media pemeliharaan baru juga salah satu faktor yang perannya sangat penting dalam menentukan besar kecilnya tingkat mortalitas larva stadia nauplius (Mc.Vey, dan Fox, 1983). Disamping itu peralihan stadia dari Nauplius ke Zoea merupakan saat yang cukup rawan terhadap kejadian peningkatan mortalitas larva udang, karena pada phase ini terjadi proses adaptasi

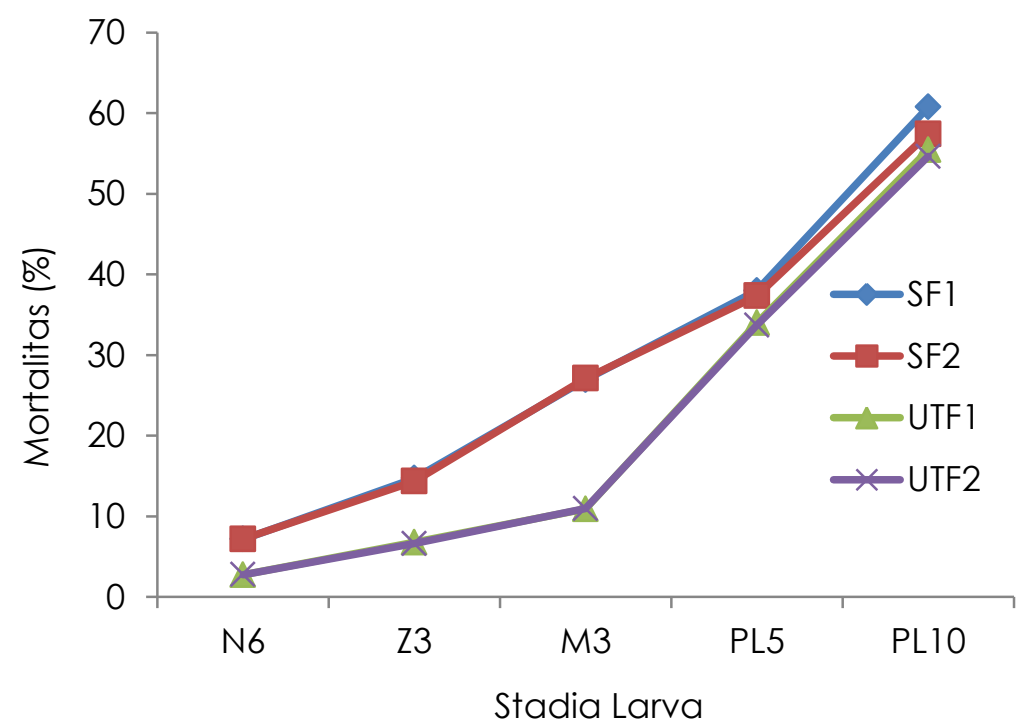

Gambar 2. Mortalitas Larva Udang Vannamei Pada Perbedaan Perlakuan Penerapan Sistim Filtrasi Air Media Pemeliharaan. 
larva udang terhadap pola pergantian penggunaan pakan dari persediaan kuning telur dari yolk saccus yang ada di dalam tubuh ke persediaan pakan yang diperoleh dari luar tubuh dengan bentuk dan jenis pakan yang berbeda. Proses adaptasi ini terjadi baik terhadap pola cara mendapatkan makanannya sampai dengan proses penyiapan enzim - enzim yang diperlukan untuk mencerna makanan. Larva udang Vannamei pada stadia Zoea dalam mendapatkan makanan dari luar tubuhnya dengan cara menyaring segala macam makanan yang sesuai dengan ukuran mulutnya masuk ke dalam tubuh. Proses ini dapat menyebabkan peningkatan mortalitas larva apabila di dalam pemberian pakan kurang cermat baik kualitas maupun kuantitasnya, sehingga pada pemberian pakan yang berlebih dapat terjadi penempelan feses yang terlalu panjang pada saluran pencernaan dan oleh karena gerakan larva selalu menuju ke depan untuk menyaring makanan dan apabila kotoran ini terkait dengan lainnya akan terjadi saling tarik menarik yang dapat menyebabkan rusaknya saluran pencernaan larva udang.

Demikian juga faktor eksternal terutama dalam kemampuannya untuk beradaptasi terhadap perubahan faktor lingkungan, seperti: suhu, salinitas, pH, ammoniak, oksigen terlarut dalam air dan sebagainya merupakan faktor penting yang sangat berpengaruh terhadap mortalitas larva udang (Mc.Vey, dan Fox, 1983).

Dilihat dari faktor $\mathrm{pH}$ air media pemeliharaan larva pada kedua perlakuan yang diterapkan (Gambar 3) menunjukkan masih cukup berfluktuasi, sehingga faktor ini pengaruhnya sangat kuat sebagai penyebab

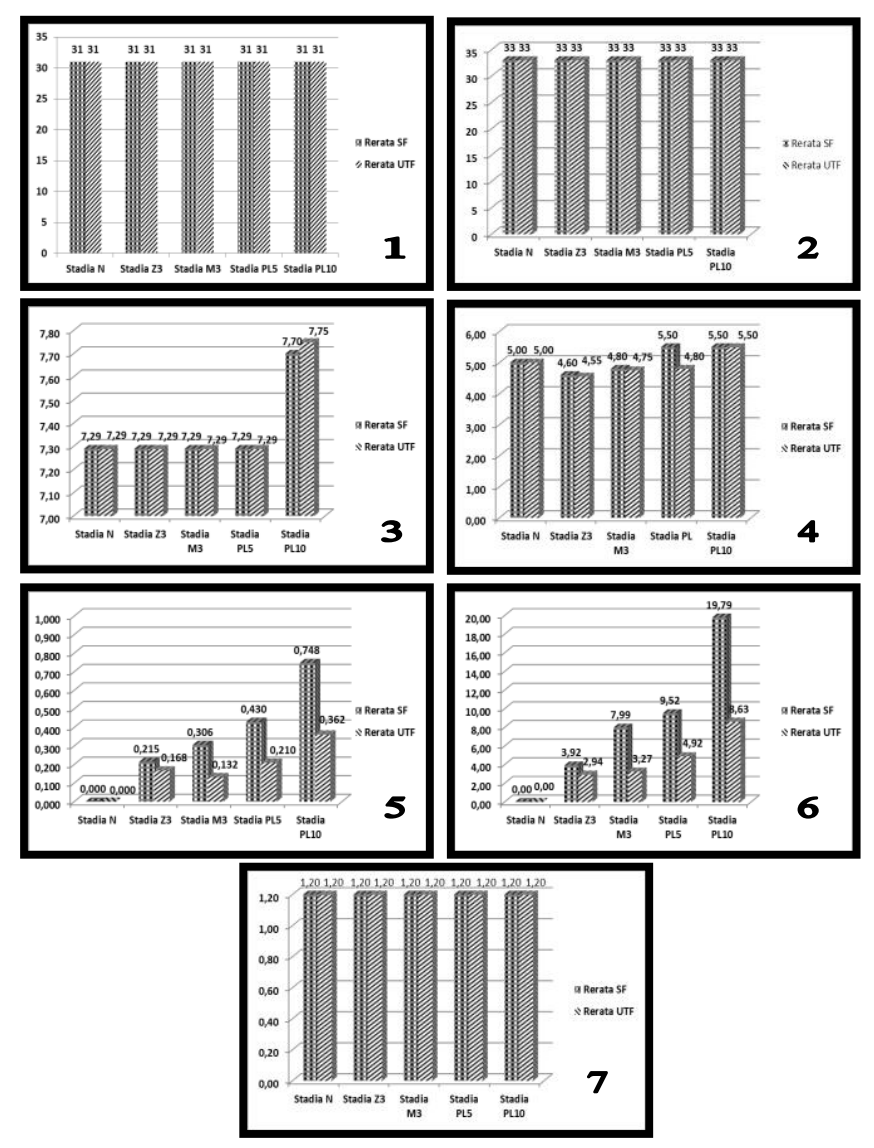

Gambar 3. Kualitas Air Media Pemeliharaan Larva, meliputi: 1. Suhu $\left({ }^{0} \mathrm{C}\right)$, 2.Salinitas (ppt), 3.pH, 4. Oksigen Terlarut dalam Air (mg/L), 5. Ammoniak $\left(\mathrm{NH}_{3}-\mathrm{N}\right)(\mathrm{mg} / \mathrm{L})$, 6. Muatan Padatan Tersuspensi (mg/L), 7. Kecerahan Air $(\mathrm{cm})$ pada Perbedaan Penerapan Pola Pemeliharaan dengan Sand Filter (SF) dan Ultra Filtrasi (UTF). 
terjadinya kenaikan mortalitas larva udang yang dipelihara selama stadia Zoea. Apabila dikaitkan dengan faktor Ammoniak $\left(\mathrm{NH}_{3}-\mathrm{N}\right)$ yang dikandung oleh air media pemeliharaan larva udang pada stadia Zoea menunjukkan adanya peningkatan yang cukup signifikan, yaitu sebesar $0,215 \mathrm{mg} / \mathrm{L}$ untuk pola pemeliharaan dengan sand filter dan 0,168 $\mathrm{mg} / \mathrm{L}$ untuk pola pemeliharaan larva udang dengan penerapan sistim ultra filtrasi (Gambar 3).

Kenaikan Ammoniak $\left(\mathrm{NH}_{3}-\mathrm{N}\right)$ di dalam air media pemeliharaan larva udang stadia Zoea ini sebagai akibat dari hasil sisa metabolisme larva udang yang dipelihara dan sisa pakan buatan yang diberikan setiap harinya. Hal ini dapat digambarkan secara jelas pada Gambar 3 bahwa kandungan ammoniak $\left(\mathrm{NH}_{3}-\mathrm{N}\right)$ yang terjadi pada setiap bak linier dengan kenaikan kandungan muatan padatan tersuspensi di dalam air media pemeliharaan larva stadia Zoea. Demikian juga pada stadia mysis dan postlarva, faktor yang sama diduga pengaruhnya sangat kuat sebagai penyebab terjadinya kenaikan mortalitas larva udang yang dipelihara selama stadia Mysis dan postlarva. Pada gambar tersebut menunjukkan bahwa larva udang Vannamei yang dipelihara pada bak yang dilengkapi dengan sistem ultra filtrasi memberikan respon kualitas air media pemeliharaan yang lebih baik dibanding dengan pada sistem pemeliharaan yang dilakukan dengan menggunakan sandfilter

\section{KESIMPULAN}

Larva udang Vannamei yang dipelihara dengan pola pemeliharaan dengan penerapan sistim ultrafiltrasi menghasilkan mortalitas yang berbeda sangat nyata dibandingkan dengan penerapan pola pemeliharaan menggunakan sand filter. Kualitas air media pemeliharaan larva udang Vannamei, seperti: suhu, salinitas, $\mathrm{pH}$, kecerahan air, oksigen terlarut dalam air masih menunjukkan dalam kisaran yang cukup baik dalam menunjang kehidupan larva, namun kandungan Ammoniak $\left(\mathrm{NH}_{3}-\mathrm{N}\right)$ dan MPT menunjukkan semakin meningkat dengan meningkatnya waktu pemeliharaan larva.

\section{UCAPAN TERIMA KASIH}

Terima kasih diucapkan kepada Direktorat Riset dan Pengabdian Masyarakat, Direktorat Jenderal Penguatan Riset dan Pengembangan, Kementerian Riset, Teknologi dan Pendidikan Tinggi yang telah membiayai penelitian ini melalui dana hibah "Penelitian Terapan Unggulan Perguruan Tinggi (PTUPT)", Sesuai dengan Kontrak Penelitian Nomor: 70063/UN7.P4.3/PP/2017, Tanggal 25 Agustus 2017.

\section{DAFTAR PUSTAKA}

Amrillah, A.M., Widyarti, S. \& Kilawati,Y. 2015. Dampak stres salinitas terhadap prevalensi white spot syndrome virus (WSSV) dan survival rate udang vannamei (Litopenaeus vannamei) pada kondisi terkontrol. Res. J. Life Sci. 2(1):110-123.

Anita, A. W., Agus, M. \& Mardiana, T.Y. 2017. Pengaruh perbedaan salinitas terhadap pertumbuhan dan kelangsungan hidup larva udang vannamei (Litopenaeus vannamei) PL-13. Pena Akuatika. 16(1):1219.

Anonimus, 2015. Peluang pasar eksport komoditas udang ke Amerika Serikat. Seefood servicecenter.com. 26 Juni 2016.

Kordi, K dan Andi B. 2007. Pengelolaan Kualitas Air Dalam Budidaya Perairan. Rineka Cipta.Jakarta

Leblanc, B.D. \& Overstreet, R.M. 1991. Efficacy of calcium hypochlorite as a desinfectant against the shrimp virus Baculovirus penaei. J. Aqua. Animal Health. 3(2):141-145.

Mc.Vey, J.P. \& Fox, J.M. 1983. Hatchery techniques for penaeid shrimp utilized by Texas A \& M-NMFS Galveston Laboratory Program. In: Mc Vey, J.P. Ed. CRC Handbook of Mariculture, Vol 1. CRC Series in Marine Sciences. p. 129-154.

Nasir, M. 1988. Metodologi Penelitian. Ghalia Indonesia, Jakarta. hlm.5-9.

NEWSKKP, 2017.. KKP Bangun Naupli Center Udang Vaname Kapasitas 450 Juta Ekor Per Tahun. 2 Juni 2017. http://news.kkp.go.id.

Steel, R.G.D. \& Torrie, T.H. 1980. Principles and Procedures of Statistics. Mc Graw Hill Book, Co., Inc., New York, 633 p.

Sudjana, 1982. Metoda Statistika. Penerbit Tarsito, Bandung.485 HIm. 
Sunaryo,1998. Einfluss von Temperatur und Eiweissangebot auf Nahrungsumsatz und Wachstum bei Jugendstadien von Penaeus monodon Fabricius, 1798. Shaker Verlag. Aachen. Germany.

Syukri, M. \& Ilham, M. 2016. Pengaruh salinitas terhadap sintasan dan pertumbuhan larva udang Windu (Penaeus monodon). J. Galung Tropika. 5(2):86 - 96.

Wenten, I G. \& Widiasa, I.N., 2004. The Role and Performance of Ultrafiltration for Clean Production in Cassava Starch Industry, Proceeding $6^{\text {th }}$ Specialist Conference on Small Water \& Wastewater Systems and $1^{\text {st }}$ International Conference on Onsite Wastewater Treatment \& Recycling, Perth, Australia

Wenten, I.G., Rahayu, L.I.N. \& Widiasa, I.N. 1998. Pengolahan Air Gambut dengan Reverse Osmosis, Prosiding Seminar Aplikasi dan Fundamental Teknik Kimia, pp 24-25

Widiasa, I.N. 2005. Reverse Osmosis: Teknologi Desalinasi Hemat Energi dan Ramah Lingkungan, Kinetika, 2005.
Widiasa, I.N. \& Wenten, I.G. 2004. Study on Membrane Fouling and Starch Rejection During Ultrafiltration of Starchy Wastewater, Prosiding Seminar Rekayasa Kimia dan Proses Teknik Kimia Undip,

Widiasa, I.N. \& Wenten, I.G. 2005. Fouling behaviour during cross flow ultrafiltration of cassava starch hydrolysate using polyacrylonitrile membrane, App. Membr. Sci. Tech, 1(1)

Widiasa, I.N. \& Wenten, I.G, 2005. Hydrolysis of native cassava starch at high dry solid in an enzymatic membrane reactor, ICOM 2005, Seoul

Widodo, A. F., Pantjara, B., Adhiyudanto, N.B. \& Rachmansyah. 2011. Performansi fisiologis udang vaname, Litopenaeus vannamei yang dipelihara pada media air tawar dengan aplikasi kalium. J. Riset Akuakul., 6(2): 225-241. 